\title{
Apoptosis and Cell Proliferation Markers in Inflammatory-Fibroproliferative Diseases of the Vessel Wall (Review)
}

\author{
DOI: $10.17691 / \mathrm{stm} 2020.12 .4 .13$
}

Received March 2, 2020

E.A. Klimentova, MD, PhD, Department of Cardiovascular, X-ray Endovascular, Operative Surgery, and Topographic Anatomy; I.A. Suchkov, MD, DSc, Professor, Department of Cardiovascular, X-ray Endovascular, Operative Surgery, and Topographic Anatomy;

A.A. Egorov, MD, PhD, Doctoral Student, Department of Cardiovascular, X-ray Endovascular, Operative Surgery, and Topographic Anatomy;

R.E. Kalinin, MD, DSc, Professor, Head of the Department of Cardiovascular, X-ray Endovascular, Operative Surgery, and Topographic Anatomy

Ryazan State Medical University, 9 Vysokovoltnaya St., Ryazan, 390026, Russia

Apoptosis is the main feature of inflammatory-fibroproliferative disorders of the vessel wall. Studies in animal models have shown that smooth muscle cells (SMCs) cultured from endarterectomy specimens from the affected area proliferate more slowly and display higher apoptotic indices than SMCs derived from the normal vessel wall. Apoptotic cells were found in the destabilized atherosclerotic plaques, as well as in the samples with restenosis of the reconstruction area.

Injury to the vessel wall causes two waves of apoptosis. The first wave is the rapid apoptosis in the media that occurs within a few hours after injury and leads to a marked reduction in the number of vascular wall cells. The second wave of apoptosis occurs much later (from several days to weeks) and is limited by the SMCs within the developing neointima. Up to $14 \%$ of the neointimal SMCs undergo apoptosis 20 days after balloon angioplasty. Ligation of the external carotid artery in a rabbit model led to a marked decrease in blood flow in the common carotid artery, which correlated with the increased apoptosis of endothelial cells and SMCs.

Angioplasty-induced death of SMCs is regulated by a redox-sensitive signaling pathway, and topical administration of antioxidants can minimize vascular cell loss. On the whole, studies show that apoptosis is prevalent in vascular lesions, controlling the viability of both inflammatory and vascular cells, determining the cellular composition of the vessel wall. The main markers of apoptosis (Fas, Fas ligand, p53, Bcl-2, Bax) and cell proliferation (toll receptor) have been considered in the current review.

Key words: apoptosis; markers of apoptosis; cell proliferation; inflammatory disorders of the vessel wall.

How to cite: Klimentova E.A., Suchkov I.A., Egorov A.A., Kalinin R.E. Apoptosis and cell proliferation markers in inflammatoryfibroproliferative diseases of the vessel wall (review). Sovremennye tehnologii v medicine 2020; 12(4): 119, https://doi.org/10.17691/ stm2020.12.4.13

\section{Introduction}

Normal vascular cells undergo little apoptosis. It is an important component of the vessel wall remodeling process that occurs during the formation of atherosclerotic and restenotic lesions [1-3]. Apoptotic death is a way to remove infiltrating leukocytes and damaged cells without developing inflammation $[4,5]$. It functions properly in the early stages of the disease, and an increase in the apoptotic rate in a later stage of the lesion is associated with insufficient removal of dying cells, the development of secondary necrosis, exacerbation of inflammation in the atherosclerotic plaque (AP).

Initially, the study of the process of apoptosis was carried out in endarterectomy samples from the zone of atherosclerotic and restenotic lesions; it was found in the macrophages, smooth muscle cells (SMCs), $T$ lymphocytes. In the initial stages of atherosclerosis, the activity of cell proliferation is higher than the rate of apoptosis, which causes atherosclerotic plaque formation and development $[6,7]$. With the progression of the process, apoptosis prevails in various cells of the AP (SMCs, fibrous cap, etc.), causing its instability and rupture with subsequent thrombosis. Clinical studies of patients with myocardial infarction have demonstrated an increase in apoptotic markers (FADD and caspase-8) in the acute phase of the event [8].

Studies of cell death in vascular lesions were carried out in animal models. In experimental studies, activation of the L-arginine/nitric oxide (NO) metabolite pathway causes regression of atheroma via the induction of

Corresponding author: Emma A. Klimentova, e-mail: klimentowa.emma@yandex.ru 
macrophage apoptosis. Increased expression of apoptotic genes of Bax proteins, caspase-3, caspase- 9 , p53, and FAS in unstable plaques was established in rabbit models [9].

Apoptotic cells (SMCs, macrophages, and leukocytes) were found in the samples with restenosis of the reconstruction zone. The analysis of the neointima after percutaneous transluminal balloon angioplasty (PTA) showed that apoptosis reaches its maximum after 2 weeks, while continuous cell proliferation occurs within 12 weeks without an increase in the cell composition. PTA induces a rapid wave of apoptosis of the SMCs in the carotid artery media. Intact vessels and vessels examined immediately after PTA display no signs of apoptosis. However, $0.5-1 \mathrm{~h}$ after injury, up to $70 \%$ of medial SMCs demonstrate nuclear condensation (an independent indicator of apoptosis), and after $4 \mathrm{~h}$ they are no longer detectable [10].

Rapid onset apoptosis has been observed in PTA models with unilateral and bilateral lesions of the rabbit iliac arteries [11]. A big amount of cell loss depended on the intensity of damage in both models, apoptosis being observed more often in the media than in the neointima. Although the quantification of apoptosis in neointimal lesions remains a matter of controversy, studies have demonstrated that the restenotic zone contains a higher SMC density and significantly reduced levels of apoptosis compared to primary atherosclerotic lesions. There is a hypothesis that the activation of the antiapoptotic gene $B c /-x L$ in neointimal cells can give them relative resistance to the induction of their death due to injury.

The immunohistochemical study of the synthetic shunts after their implantation into the vascular bed showed the presence of apoptotic cells in the intima after 1 month, and in the graft adventitia after 6 months. Until now, the mechanisms and role of macrophages in the distribution of these cells in the vessel walls are not fully known. Macrophages induce Fas upregulation in the cultured SMCs [12-14].

On modeling a venous shunt in experiments on rabbits, Wan et al. [15] showed that the level of apoptosis is highest between the $1^{\text {st }}$ and $3^{\text {rd }}$ days after surgery, while proliferation reaches its maximum on the $7^{\text {th }}$ day. As the restenosis of the venous graft progresses, signs of apoptosis are revealed.

Pro-oncogenic c-Myc controls cell proliferation, apoptosis, tissue remodeling, angiogenesis, cell metabolism, and the production of inflammatory and anti-inflammatory cytokines [16-21]. Steger et al. [22] showed that the use of an antisense oligonucleotide against c-Myc in a mouse venous graft model involves a significant reduction in neointima formation in the postoperative period.

Percutaneous transluminal balloon angioplastyinduced death of SMCs is regulated via redox-sensitive signaling pathways, and local administration of antioxidants can minimize the loss of vascular wall cells
[23-29]. Lipophilic statin use causes apoptosis of various types of cells, including SMCs and endothelial cells, while hydrophilic statins (rosuvastatin and pravastatin) do not. Clinical significance of statin-induced apoptosis remains controversial since it can reduce the thickening of the vascular wall in the early stages of atherosclerosis, as well as reduce the formation of neointima in response to damage on the one hand, and on the other hand, it can promote the atherosclerotic plaque destabilization causing acute cardiovascular events [30-34].

\section{Apoptosis markers}

Fas receptor and its ligand. One of the main participants in the apoptosis system is the Fas receptor and its ligand. Fas ligand (FasL) is a type II membrane protein that belongs to the tumor necrosis factor family and induces apoptosis through a cognate interaction with the Fas receptor (CD95/Apo-1). The Fas-FasL system is involved in the regulation of physiological cell metabolism. Fas contains a cytoplasmic domain called the death domain (Fas-associated death domain), which is required for transmission of an apoptotic signal. The Fas death domain interacts with the FADD protein. A separate FADD domain binds to procaspase-8. Fas leads to caspase-8 activation through autoproteolysis followed by proteolytic cleavage of other members of the caspase family. Caspase- 8 activation and Fas-mediated apoptosis can be blocked by endogenous inhibitory molecules such as FLIP (FLICE-like inhibitory proteins) $[35,36]$.

Fas-mediated death signaling may involve the activation of anti-apoptotic proteins $\mathrm{Bcl}-2$ and $\mathrm{Bcl}-$ $\mathrm{XL}$. Mitochondrial activation results from caspase-8mediated cleavage of the Bid protein, which is then translocated into the mitochondrial membrane and induces cytochrome release [37].

Fas is expressed on many types of cells, including inflammatory and vascular ones. FasL was found in inflammatory cells and tissues, vascular endothelium, where it played an important role in controlling the extravasation of inflammatory cells. Endogenous FasL mainly functions to suppress inflammatory responses, its non-physiological expression can cause neutrophil infiltration due to the release of IL-1 $\beta$ and neutrophilic chemoattractant after Fas activation. Since SMCs express Fas, and inflammatory cells express FasL, it has been suggested that Fas-mediated apoptosis may promote AP instability. Local delivery of FasL to the carotid arteries of the rats after PTA induced apoptosis in proliferating SMCs [38, 39].

Unlike SMCs, vascular endothelial cells are resistant to Fas-mediated apoptosis under normal conditions. Endothelial cells with Fas on their surface do not undergo apoptosis when exposed to an agonist anti-Fas antibody or when FasL is increased through adenoviral delivery. They remain resistant to Fas-mediated cell death even when activated by interferon- $\gamma$, which 
markedly increases Fas expression. This occurs due to low FasL synthesis on the cell surface, production of endogenous inhibitors of the Fas pathway of death signaling, or FLIP expression, which ensures their survival. Other defense mechanisms may include the involvement of the $\mathrm{Bcl}-2$ family proteins which function as positive and negative regulators of apoptosis. NO production by endothelial cells promotes the nitrosylation and inactivation of the caspases which are required for Fas-mediated cell death. An interesting fact is that NO released from the SMCs of IL-1 stimulated rats promotes Fas expression independently of cGMP [40].

Local administration of TNF- $\alpha$ to arteries inhibits endothelial FasL and induces strong leukocyte infiltration of the vessel wall. TNF- $\alpha$ secretion by activated cells within atheroma can inhibit FasL expression in the adjacent cells of normal endothelium, promoting increased extravasation of leukocytes and wall damage. TNF- $\alpha$-induced macrophage and $T$ cell infiltration is markedly attenuated when Fas $L$ is constitutively expressed in vascular endothelium by adenovirus-mediated gene transfer. Chronic localized immune response is a hallmark of atherogenesis. The observation that FasL is able to inhibit inflammatory responses in the vessel wall suggests that it may have an atheroprotective function [41].

On the other hand, changes in the expression of FasL and Fas may indicate endothelial cell dysfunction, which promotes atherogenesis. For example, oxidized low-density lipoproteins (LDL) can alter the sensitivity of these cells to Fas-mediated apoptosis. Sensitization of Fas-mediated apoptosis correlates with suppression of FLIP and estimates the role of this inhibitor in the natural resistance of endothelial cells to Fas stimulation [41].

English et al. [42] proved that the tissue inhibitor of metalloproteinases-3 (TIMP3) induces apoptosis in human SMCs via caspase-8 and FAS activation. Imanishi et al. [43] showed that a decrease in FLIP synthesis in the media is observed 24 and $48 \mathrm{~h}$ after PTA, and its return to the initial level occurs on the $28^{\text {th }}$ day.

Neointimal formation after PTA is the Achilles heel of this type of treatment. PTA results in the immediate loss of SMCs due to apoptosis, followed by their rapid proliferation. It was established [44] that forced expression of FasL through adenoviral delivery in vivo reduces neointimal formation after PTA in rabbits and rats.

Luo et al. [45] compared the efficiency of the delivery of FasL and p21 protein genes by their ability to inhibit neointimal hyperplasia in the area of surgery on the carotid arteries of rats. Only Ad-FasL inhibited neointima formation in the immunized rats markedly reducing infiltration by $T$ cells. Local delivery of FasL has two effects on the vessel wall: it induces apoptosis in Fasbearing SMCs and inhibits the destructive response of T lymphocytes to the cells expressing viral proteins.

On the other hand, the formation of neointimal hyperplasia caused by the simulation of mechanical damage to the femoral artery in normal mice or by FasL or Fas deficiency did not differ, which indicates the existence of other signaling pathways of apoptosis in vessel wall injury [46].

Toll-like receptors (TLR). It is a class of cellular receptors with a single transmembrane fragment that recognize microorganisms and activate cellular immune response. Today, 13 types of TLR are known, only 9 types have been found in humans. They are presented on cells of different types - from epithelial to immunocompetent ones. For example, TLR4 is expressed on cardiomyocytes, macrophages, SMCs, and endothelial cells. The known TLR ligands are various bacterial and fungal components including peptidoglycan for TLR2, lipopolysaccharide for TLR4, phagellin for TLR5, etc. Cellular fibronectin produced in response to tissue damage, HSP60 and HSP70 heat shock proteins, LDL, necrotic cells are activators for TLR2 and TLR4. An interesting fact is that human HSP60 requires TLR4 activation to stimulate TNF- $\alpha$ and NO production [47].

The TLR mechanism of action includes signal transduction into the cell nucleus and dimerization, accompanied by altering the conformation of the TIR domain, which binds to the MyD88 adapter molecule required for recruiting IRAK (IL-1 receptor-associated kinase) family kinases [48-51].

Toll-like receptors initiate the activation of nuclear factor (NF-KB), leading to the production of proinflammatory cytokines and chemokines such as IL-1 $1 \alpha$, IL-1 $\beta$, IL-1Ra, IL-6, IFN- $\gamma$, interferon-induced protein-10 (IP-10), inflammatory protein of macrophages (MIP-1 $\beta$ ), chemotactic protein-1 of monocytes (MCP-1), IL-8. These inflammatory mediators can exert various atherogenic effects including the expression of adhesion molecules on endothelial cells, SMC proliferation, immune cell activation, and the stimulation of the acute phase response. There is evidence of the involvement of NF-KB in the development of atherosclerosis [52-56]. Michelsen et al. [57] reported that macrophage-specific inhibition of the NF-KB pathway leads to a more severe course of atherosclerosis in mice (possibly due to a decrease in IL-10 production by macrophages).

In recent years, evidence has emerged regarding TLR involvement in the pathogenesis of atherosclerosis. Normal arteries displayed very low levels of all TLRs with the exception of a relatively higher level of TLR4 mRNA. In the atherosclerotic lesion area, TLR1, TLR2, and TLR4 were increased threefold, their synthesis is carried out predominantly by endothelial cells and macrophages. In a mouse model with a TLR4/ApoE deficiency, a lower formation of atherosclerotic plaques with a stable phenotype was displayed due to the reduced levels of IL-12, MCP-1, etc. Disabling MyD88, an adapter molecule of the TLR signaling pathway in ApoE-I- mice, decreased the number of atherosclerotic lesions of the aorta by $40-65 \%$ and significantly reduced the formation of cyclooxygenase- 2 in the atherosclerotic 
plaques. Thus, TLR4 and MyD88 are key players in the progression of atherosclerosis [58].

Toll-like receptor-2 promotes SMC migration by increasing IL-6 production. Numerous studies [5962] show that the receptor agonists stimulate the migration of SMCs, but not cell proliferation and viability. Deficiency of the receptor or its inhibition by an antibody inhibits TLR2 agonist-induced SMC migration and IL-6 production mediated by p38 mitogen-associated protein kinase and extracellular kinase 1 and 2 signals. These signaling pathways work together to activate CAMP and subsequent IL-6 production, which, in turn, contributes to SMC migration. The use of antibodies against IL-6 disrupted TLR2-mediated SMC migration. Schoneveld et al. [63] in their experiment demonstrate the local application of a specific ligand to stimulate TLR2 on the femoral artery of mice, inducing the formation of vascular neointimal hyperplasia. Kobayashi et al. [64] found in animal models that infection with Porphyromonas gingivalis can promote neointima formation after arterial injury by signaling through TLR2. Zhang et al. showed [65] that palmitate-induced generation of reactive oxygen species and SMC apoptosis, accompanied by the inhibition of the caspase-3, caspase-9, and p53 expression, as well as Bcl-2 expression restoration, were significantly blocked in mice lacking TLR4.

In the patients with Asp299Gly TLR4 gene polymorphism, less intima/media thickness in the carotid artery was observed than in healthy volunteers. The patients with this polymorphism suffering from ischemic heart disease demonstrated greater benefit from treatment with pravastatin (HMG-CoA reductase inhibitor) compared to healthy volunteers [66].

Proteins of the Bcl-2 family. In many situations, cell viability is controlled by modulation of the levels of the $\mathrm{Bcl}-2$ family proteins. Some of these proteins (Bcl-2, Bcl$X L$, and $A 1$ ) act as inhibitors of apoptosis, while others (Bax, Bad, and Bid) are modulators. The ratio of these proteins is believed to control cell survival [67-70].

As a rule, proteins of the $\mathrm{Bcl}-2$ family function at the mitochondrial level, control cell viability, as well as the movement and action of cytochrome $\mathrm{C}$, which accelerates apoptotic cell death. When the Apaf-1 protein is released from mitochondria, cytochrome $\mathrm{C}$ binds to it and pro-caspase- 9 , which results in the proteolytic activation of this caspase. Then caspase-9 proteolytically activates downstream caspases and cell death occurs. The Bcl-XL protein forms an ion channel in the synthetic lipid membranes, regulating mitochondrial function and membrane permeability [71-74].

The Bax protein level is elevated in the SMCs of human atherosclerotic plaques where apoptosis occurs at a high rate [75]. On the contrary, the protective factor for Bcl-XL apoptosis is detected in normal SMCs of rat media, and its expression is rapidly decreased after PTA. A decrease in Bcl-XL occurs $1 \mathrm{~h}$ after injury in the media. Increased Bcl-XL levels were observed in the atheromatous lesions of the human intima in comparison to the media cells. When an antisense oligonucleotide directed against $\mathrm{Bcl}-\mathrm{XL}$ was injected into the balloondamaged carotid arteries of a rabbit 4 weeks after the procedure, $\mathrm{Bcl}-\mathrm{XL}$ expression was suppressed and intimal cell apoptosis occurred at an increased rate. This resulted in a $56 \%$ reduction in intimal thickness. The studies have demonstrated that the $\mathrm{Bcl}-2$ family proteins are functionally significant in the vessel wall and differential expression of $\mathrm{Bcl}-\mathrm{XL}$ can contribute to the differential sensitivity of medial and neointimal cells to rapid apoptosis [76-78].

p53 transcription factor. The fact that the p53 transcription factor activates Bax expression and inhibits the $\mathrm{Bcl}-2$ protein, which leads to conditions promoting apoptosis, may be significant in the disease of the vessel wall $[79,80]$. Activation of p53 also increases Fas expression on the cell surface of human SMCs, stimulating transport from the Golgi apparatus. The antiproliferative activity of p53 is mediated by its ability to induce a p21 cyclin-dependent kinase inhibitor. The p53 factor can induce SMC apoptosis in vitro and inhibit SMC proliferation in vitro and in vivo. It is accumulated in atherosclerotic lesions, and its ability to initiate apoptosis in these lesions may depend on interaction with MDM2 protein, a regulator of p53 stability [81-84]. It was reported [85] that the cytomegalovirus gene counteracts p53-induced apoptosis of SMCs. Mice deficient in this protein, developed accelerated atherosclerotic aortic lesions when fed a high-fat diet compared to healthy mice. However, the increased lesion size due to p53 deficiency appears to be the result of an increase in the rate of cell proliferation rather than a decrease in apoptosis. Thus, p53-independent apoptotic mechanisms may predominate in the atherogenic vessel wall $[86,87]$.

The functions of the Bcl-2 family proteins also include the regulation of the viability of endothelial cells. For example, endothelial cell survival is facilitated by vascular endothelial growth factor (VEGF), which is associated with increased $\mathrm{Bcl}-2$ levels. Protein kinase activation is required for VEGF-mediated endothelial cell survival and VEGF-mediated induction of Bcl-2. TNF- $\alpha$-induced endothelial cell death includes Bcl-2 degradation $[88,89]$.

Nitric oxide, synthesized from L-arginine with the help of NO synthases, is a small, lipophilic, diffusing, highly reactive molecule with a dichotomous regulatory role in many biological events under physiological and pathological conditions [90]. NO can promote apoptosis in some cells and inhibit apoptosis in others. The local cellular environment plays a dynamic role in determining the nature of these types of regulation [91, 92]. Important components of the microenvironment are as follows: the redox state of cells, glutathione, the presence of other oxygen- and nitrogen-centered radicals. High NO production acts as a pro-apoptotic modulator, activating proteases of the caspase family through the mitochondrial cytochrome $C$ release into 
the cytosol, p53 protein up-regulation, activation of the JNK/SAPK signaling pathway, by altering the expression of the apoptosis-associated proteins of the Bcl-2 family. Nevertheless, low or physiological concentrations of $\mathrm{NO}$ inhibit cell apoptosis induced by Fas, LDL, and cytokines. The antiapoptotic mechanism is associated with gene transcription of protective proteins ( $\mathrm{Bcl}-2$, heat shock protein, cyclooxygenase-2) and direct inhibition of effector caspases by S-nitrosylation of the thiol group of cysteine in their catalytic site [93-97]. Recent studies on hypercholesterolemic rabbits have demonstrated that activation of the L-arginine/NO pathway causes atheroma regression, most likely through the induction of macrophage apoptosis. Dubey et al. [98] demonstrated the decisive role of inducible NO synthase in neutrophil apoptosis through enhanced generation of reactive oxygen species and caspase-8-mediated activation of the mitochondrial death pathway. NO increases Fas expression on SMCs, which enhances their apoptosis under these conditions $[99,100]$.

\section{Conclusion}

Cell apoptosis is widespread in inflammatoryfibroproliferative lesions of the vessel wall. Cell death can affect lesion volume, plaque stability, inflammation, and endothelial integrity. Recent research has identified numerous regulatory pathways that could potentially control vascular cell viability. Understanding these regulatory networks at the molecular level will help to form the understanding of the pathogenesis of vascular diseases and lead to the development of new treatments for these disorders.

Authors' contributions. E.A. Klimentova, development of the conception and design of the study, acquisition of data, data analysis, preparation of the text; I.A. Suchkov and A.A. Egorov, text editing; R.E. Kalinin, development of the conception and design of the study, editing.

Study funding. The work was supported by the Ryazan State Medical University.

Conflict of interests. The authors have no conflict of interests to declare.

\section{References}

1. Pshennikov A.S., Deev R.V. Morphological illustration of alterations in the arterial endothelium in ischemic and reperfusion injuries. Rossiyskiy mediko-biologicheskiy vestnik im. akademika I.P. Pavlova 2018; 26(2): 184-194, https://doi. org/10.23888/pavlovj2018262184-194.

2. Kalinin R.E., Suchkov I.A., Pshennikov A.S. The effectiveness of L-arginine in the treatment of atherosclerosis of the arteries of the lower extremities and the prevention of restenosis of the reconstruction zone. Vestnik Ivanovskoy meditsinskoy akademii 2013; 18(2): 18-21.

3. D'Arcy M.S. Cell death: a review of the major forms of apoptosis, necrosis and autophagy. Cell Biol Int 2019; 43(6): 582-592, https://doi.org/10.1002/cbin.11137.
4. Egorova I.E., Bakhtairova V.I., Suslova A.I. Molecular mechanisms of apoptosis involved in the development of different pathological processes. Innovatsionnye tekhnologii $v$ farmatsii 2019; 6: 107-114.

5. Mayboroda A.A. Apoptosis - genes and proteins. Sibirskij medicinskij zhurnal 2013; 3: 130-135.

6. Cheng X., Ferrell J.E. Jr. Apoptosis propagates through the cytoplasm as trigger waves. Science 2018; 361(6402): 607-612, https://doi.org/10.1126/science.aah4065.

7. Walsh K., Smith R.C., Kim H.S. Vascular cell apoptosis in remodeling, restenosis, and plaque rupture. Circ Res 2000; 87(3): 184-188, https://doi.org/10.1161/01.res.87.3.184.

8. Prech M., Marszałek A., Schröder J., Filas V., Lesiak M., Jemielity M., Araszkiewicz A., Grajek S. Apoptosis as a mechanism for the elimination of cardiomyocytes after acute myocardial infarction. Am J Cardiol 2010; 105(9): 1240-1245, https://doi.org/10.1016/j.amjcard.2009.12.039.

9. Meng L.B., Shan M.J., Yu Z.M., Lv J., Qi R.M., Guo P., Zhang Y.M., Gong T. Chronic stress: a crucial promoter of cell apoptosis in atherosclerosis. $J$ Int Med Res 2019; 48(1): 300060518814606, https://doi. org/10.1177/0300060518814606.

10. Han D.K., Haudenschild C.C., Hong M.K., Tinkle B.T., Leon M.B., Liau G. Evidence for apoptosis in human atherogenesis and in a rat vascular injury model. Am J Pathol 1995; 147(2): 267-277.

11. Rivard A., Luo Z., Perlman H., Fabre J.E., Nguyen T., Maillard L., Walsh K. Early cell loss after angioplasty results in a disproportionate decrease in percutaneous gene transfer to the vessel wall. Hum Gene Ther 1999; 10(5): 711-721, https:// doi.org/10.1089/10430349950018472.

12. Huang P., Hawthorne W.J., Ao P., Angeli G.L., Medbury H.J., Fletcher J.P. Perigraft adventitia and intima remodeling after synthetic patch implantation in sheep carotid artery: role of apoptosis and proliferation. J Vasc Surg 2002; 36(2): 371-378, https://doi.org/10.1067/mva.2002.123749.

13. Durham A.L., Speer M.Y., Scatena M., Giachelli C.M., Shanahan C.M. Role of smooth muscle cells in vascular calcification: implications in atherosclerosis and arterial stiffness. Cardiovasc Res 2018; 114(4): 590-600, https://doi. org/10.1093/cvr/cvy010.

14. Grootaert M.O.J., Moulis M., Roth L., Martinet W., Vindis C., Bennett M.R., De Meyer G.R.Y. Vascular smooth muscle cell death, autophagy and senescence in atherosclerosis. Cardiovasc Res 2018; 114(4); 622-634, https://doi.org/10.1093/cvr/cvy007.

15. Wan L., Dai S.H., Lai S.Q., Liu L.Q., Wang Q., Xu H., Wang W.J., Liu J.C. Apoptosis, proliferation, and morphology during vein graft remodeling in rabbits. Genet Mol Res 2016; 15(4): 371-378, https://doi.org/10.4238/gmr.15048701.

16. Ansari M.Z., Swaminathan R. Structure and dynamics at $\mathrm{N}$ and $\mathrm{C}$-terminal regions of intrinsically disordered human c-Myc PEST degron reveal a $\mathrm{pH}$-induced transition. Proteins 2020; 88: 889-909, https://doi.org/10.1002/prot.25880

17. Wei X., Zhang Y., Li C., Ai K., Li K., Li H., Yang J. The evolutionarily conserved MAPK/Erk signaling promotes ancestral T-cell immunity in fish via c-Myc-mediated glycolysis. J Biol Chem 2020; 295(10): 3000-3016, https://doi. org/10.1074/jbc.RA119.012231.

18. Date Y., Ito K. Oncogenic RUNX3: a link between p53 deficiency and MYC dysregulation. Mol Cells 2020; 43(2): 176181, https://doi.org/10.14348/molcells.2019.0285.

19. Olivero C.E., Martínez-Terroba E., Zimmer J., Liao C., 
Tesfaye E., Hooshdaran N., Schofield J.A., Bendor J., Fang D., Simon M.D., Zamudio J.R., Dimitrova N. p53 activates the long noncoding RNA Pvt1b to inhibit Myc and suppress tumorigenesis. Mol Cell 2020; 77(4): 761.e8-774.e8, https:// doi.org/10.1016/j.molcel.2019.12.014.

20. Lee D.H., Kwon N.E., Lee W.J., Lee M.S., Kim D.J., Kim J.H., Park S.K. Increased O-GIcNAcylation of c-Myc promotes pre-B cell proliferation. Cells 2020; 9(1): E158, https://doi.org/10.3390/cells9010158.

21. Yin W., Xia X., Wu M., Yang H., Zhu X., Sun W., Ge M. The impact of BCL-2/MYC protein expression and gene abnormality on primary central nervous system diffuse large B-cell lymphoma. Int J Clin Exp Pathol 2019; 12(6): 2215-2223.

22. Steger C.M., Bonaros N., Rieker R.J., Bonatti J., Schachner T. Gene therapy with antisense oligonucleotides silencing c-myc reduces neointima formation and vessel wall thickness in a mouse model of vein graft disease. Exp Mol Pathol 2018; 105(1): 1-9, https://doi.org/10.1016/j. yexmp.2018.05.003

23. Wu Z., Zheng X., Meng L., Fang X., He Y., Li D., Zheng C., Zhang H. a-Tocopherol, especially $\alpha$-tocopherol phosphate, exerts antiapoptotic and angiogenic effects on rat bone marrow-derived endothelial progenitor cells under highglucose and hypoxia conditions. J Vasc Surg 2018; 67(4): 1263-1273.e1, https://doi.org/10.1016/j.jvs.2017.02.051.

24. Shukla S.K., Sharma S.B., Singh U.R. Pre-treatment with $\alpha$-tocopherol and terminalia arjuna ameliorates, proinflammatory cytokines, cardiac and apoptotic markers in myocardial infracted rats. Redox Rep 2015; 20(2): 49-59, https://doi.org/10.1179/1351000214Y.0000000104.

25. Vineetha R.C., Binu P., Arathi P., Nair R.H. L-ascorbic acid and $\alpha$-tocopherol attenuate arsenic trioxide-induced toxicity in $\mathrm{H} 9 \mathrm{c} 2$ cardiomyocytes by the activation of Nrf2 and Bcl2 transcription factors. Toxicol Mech Methods 2018; 28(5): 353-360, https://doi.org/10.1080/15376516.2017.1422578.

26. Arias-Álvarez M., García-García R.M., López-Tello J., Rebollar P.G., Gutiérrez-Adán A., Lorenzo P.L. $\alpha$-Tocopherol modifies the expression of genes related to oxidative stress and apoptosis during in vitro maturation and enhances the developmental competence of rabbit oocytes. Reprod Fertil Dev 2018; 30(12): 1728-1738, https://doi.org/10.1071/rd17525.

27. Bozaykut P., Karademir B., Yazgan B., Sozen E., Siow R.C., Mann G.E., Ozer N.K. Effects of vitamin E on peroxisome proliferator-activated receptor $\gamma$ and nuclear factorerythroid 2-related factor 2 in hypercholesterolemia-induced atherosclerosis. Free Radic Biol Med 2014; 70: 174-181, https://doi.org/10.1016/j.freeradbiomed.2014.02.017.

28. Shibata A., Nakagawa K., Tsuduki T., Miyazawa T. $\alpha$-Tocopherol suppresses antiangiogenic effect of $\delta$-tocotrienol in human umbilical vein endothelial cells. J Nutr Biochem 2015; 26(4): 345-350, https://doi.org/10.1016/j.jnutbio.2014.11.010.

29. Do M.h., Kim S.n., Seo S.Y., Yeo E.J., Kim S.Y. $\delta$-Tocopherol prevents methylglyoxal-induced apoptosis by reducing ROS generation and inhibiting apoptotic signaling cascades in human umbilical vein endothelial cells. Food Funct 2015; 6(5): 1568-1577, https://doi.org/10.1039/c4fo01110d.

30. Knapp A.C., Huang J., Starling G., Kiener P.A. Inhibitors of HMG-CoA reductase sensitize human smooth muscle cells to Fas-ligand and cytokine-induced cell death. Atherosclerosis 2000; 152(1): 217-227, https://doi.org/10.1016/s00219150(99)00462-1.

31. Broniarek I., Jarmuszkiewicz W. Statins and mitochondria. Postepy Biochem 2016; 62(2): 77-84.
32. Katsiki N., Tziomalos K., Chatzizisis Y., Elisaf M., Hatzitolios A.I. Effect of HMG-CoA reductase inhibitors on vascular cell apoptosis: beneficial or detrimental? Atherosclerosis 2010; 211(1): 9-14, https://doi.org/10.1016/j. atherosclerosis.2009.12.028

33. Prasad K. Do statins have a role in reduction/prevention of post-PCl restenosis? Cardiovasc Ther 2013; 31(1): 12-26, https://doi.org/10.1111/j.1755-5922.2011.00302.x.

34. Erl W., Hristov M., Neureuter M., Yan Z.Q., Hansson G.K., Weber P.C. HMG-CoA reductase inhibitors induce apoptosis in neointima-derived vascular smooth muscle cells. Atherosclerosis 2003; 169(2): 251-258, https://doi. org/10.1016/s0021-9150(03)00201-6.

35. Kolben T., Jeschke U., Reimer T., Karsten N., Schmoeckel E., Semmlinger A., Mahner S., Harbeck N., Kolben T.M. Induction of apoptosis in breast cancer cells in vitro by Fas ligand reverse signaling. $J$ Cancer Res Clin Oncol 2018; 144(2): 249-256, https://doi.org/10.1007/s00432-0172551-y.

36. Liu Y., Ren L., Liu W., Xiao Z. MiR-21 regulates the apoptosis of keloid fibroblasts by caspase- 8 and the mitochondria-mediated apoptotic signaling pathway via targeting FasL. Biochem Cell Biol 2018; 96(5): 548-555, https://doi.org/10.1139/bcb-2017-0306.

37. Mehrbod P., Ande S.R., Alizadeh J., Rahimizadeh S., Shariati A., Malek H., Hashemi M., Glover K.K.M., Sher A.A., Coombs K.M., Ghavami S. The roles of apoptosis, autophagy and unfolded protein response in arbovirus, influenza virus, and HIV infections. Virulence 2019; 10(1): 376-413, https://doi. org/10.1080/21505594.2019.1605803

38. Guégan J.P., Legembre P. Nonapoptotic functions of Fas/CD95 in the immune response. FEBS J 2018; 285(5): 809-827, https://doi.org/10.1111/febs.14292.

39. Matter C.M., Chadjichristos C.E., Meier P., von Lukowicz T., Lohmann C., Schuler P.K., Zhang D., Odermatt B., Hofmann E., Brunner T., Kwak B.R., Lüscher T.F. Role of endogenous Fas (CD95/Apo-1) ligand in ballooninduced apoptosis, inflammation, and neointima formation. Circulation 2006; 113(15): 1879-1887, https://doi.org/10.1161/ CIRCULATIONAHA.106.611731.

40. Fukuo K., Hata S., Suhara T., Nakahashi T., Shinto Y., Tsujimoto Y., Morimoto S., Ogihara T. Nitric oxide induces upregulation of Fas and apoptosis in vascular smooth muscle. Hypertension 1996; 27(3 Pt 2): 823-826, https://doi. org/10.1161/01.hyp.27.3.823.

41. Faletti L., Peintner L., Neumann S., Sandler S., Grabinger T., Mac Nelly S., Merfort I., Huang C.H., Tschaharganeh D., Kang T.W., Heinzmann F., D'Artista L., Maurer U., Brunner T., Lowe S., Zender L., Borner C. TNFa sensitizes hepatocytes to FasL-induced apoptosis by NFKBmediated Fas upregulation. Cell Death Dis 2018; 9(9): 909, https://doi.org/10.1038/s41419-018-0935-9.

42. English W.R., Ireland-Zecchini H., Baker A.H., Littlewood T.D., Bennett M.R., Murphy G. Tissue inhibitor of metalloproteinase-3 (TIMP-3) induces Fas dependent apoptosis in human vascular smooth muscle cells. PLOS One 2018; 13(4): e0195116, https://doi.org/10.1371/journal. pone. 0195116 .

43. Imanishi T., McBride J., Ho Q., O'Brien K.D., Schwartz S.M., Han D.K. Expression of cellular FLICEinhibitory protein in human coronary arteries and in a rat vascular injury model. Am J Pathol 2000; 156(1): 125-137, https://doi.org/10.1016/S0002-9440(10)64712-8. 
44. Sata M., Perlman H., Muruve D.A., Silver M., Ikebe M., Libermann T.A., Oettgen P., Walsh K. Fas ligand gene transfer to the vessel wall inhibits neointima formation and overrides the adenovirus-mediated $\mathrm{T}$ cell response. Proc Natl Acad Sci U S A 1998; 95(3): 1213-1217, https://doi.org/10.1073/ pnas.95.3.1213.

45. Luo Z., Sata M., Nguyen T. Adenovirus-mediated delivery of Fas ligand inhibits intimal hyperplasia after balloon injury in immunologically primed animals. Circulation 1999; 99(14): 1776-1779, https://doi.org/10.1161/01.cir.99.14.1776.

46. Sata M., Sugiura S., Yoshizumi M., Ouchi Y., Hirata Y., Nagai R. Acute and chronic smooth muscle cell apoptosis after mechanical vascular injury can occur independently of the Fasdeath pathway. Arterioscler Thromb Vasc Biol 2001; 21(11): 1733-1737, https://doi.org/10.1161/hq1201.098946.

47. Anthoney N., Foldi I., Hidalgo A. Toll and toll-like receptor signalling in development. Development 2018; 145(9): dev156018, https://doi.org/10.1242/dev.156018.

48. Dishon S., Schumacher-Klinger A., Gilon C., Hoffman A., Nussbaum G. Myristoylation confers oral bioavailability and improves the bioactivity of c(MyD 4-4), a cyclic peptide inhibitor of MyD88. Mol Pharm 2019; 16(4): 1516-1522, https://doi. org/10.1021/acs.molpharmaceut.8b01180.

49. Wu K., Zhang H., Fu Y., Zhu Y., Kong L., Chen L., Zhao F., Yu L., Chen X. TLR4/MyD88 signaling determines the metastatic potential of breast cancer cells. Mol Med Rep 2018; 18(3): 3411-3420, https://doi.org/10.3892/mmr.2018.9326.

50. Zhu Y., Li Y., Zhang N., Dong G.R. Effect of electroacupuncture preconditioning on myocardial ischemia and expression of TLR 4, MyD 88 and NF-KB mRNAs in "Neiguan" (PC 6) area in rats with myocardial ischemiareperfusion injury. Zhen Ci Yan Jiu 2018; 43(5): 302-306, https://doi.org/10.13702/j.1000-0607.170308.

51. Feng G., Zheng K., Cao T., Zhang J., Lian M., Huang D., Wei C., Gu Z., Feng X. Repeated stimulation by LPS promotes the senescence of DPSCs via TLR4/MyD88-NF-kB-p53/p21 signaling. Cytotechnology 2018; 70(3): 1023-1035, https://doi. org/10.1007/s10616-017-0180-6.

52. Cen X., Liu S., Cheng K. The role of toll-like receptor in inflammation and tumor immunity. Front Pharmacol 2018; 9: 878-885, https://doi.org/10.3389/fphar.2018.00878.

53. Liu J., Geng F., Sun H., Wang X., Zhang H., Yang Q., Zhang J. Candida albicans induces TLR2/MyD88/NF-KB signaling and inflammation in oral lichen planus-derived keratinocytes. J Infect Dev Ctries 2018; 12(9): 780-786, https://doi.org/10.3855/jidc.8062.

54. Cao C., An R., Yu Y., Dai H., Qu Z., Gao M., Wang J. BICP0 negatively regulates TRAF6-mediated NF-KB and interferon activation by promoting $\mathrm{K} 48$-linked polyubiquitination of TRAF6. Front Microbiol 2020; 10: 3040, https://doi. org/10.3389/fmicb.2019.03040.

55. Li X., Li H., Dong X., Wang X., Zhu J., Cheng Y., Fan P. Expression of NF-KB and TLR-4 is associated with the occurrence, progression and prognosis of esophageal squamous cell carcinoma. Int J Clin Exp Pathol 2018; 11(12): 5850-5859.

56. Shao Q., Jiang C., Xia Y., Zhao M., Zhang Q., Jin B., Liu J. Dioscin ameliorates peritoneal fibrosis by inhibiting epithelial-to-mesenchymal transition of human peritoneal mesothelial cells via the TLR4/MyD88/NF-KB signaling pathway. Int J Clin Exp Pathol 2019; 12(3): 867-875.

57. Michelsen K.S., Wong M.H., Shah P.K., Zhang W., Yano J., Doherty T.M., Akira S., Rajavashisth T.B., Arditi M.
Lack of Toll-like receptor 4 or myeloid differentiation factor 88 reduces atherosclerosis and alters plaque phenotype in mice deficient in apolipoprotein E. Proc Natl Acad Sci U S A 2004; 101: 10679-10684, https://doi.org/10.1073/pnas.0403249101.

58. Faghfouri A.H., Zarrin R., Maleki V., Payahoo L., Khajebishak Y. A comprehensive mechanistic review insight into the effects of micronutrients on toll-like receptors functions. Pharmacol Res 2019; 152: 104619, https://doi.org/10.1016/j. phrs.2019.104619.

59. Zheng C., Chen J., Chu F., Zhu J., Jin T. Inflammatory role of TLR-MyD88 signaling in multiple sclerosis. Front Mol Neurosci 2020; 12: 314, https://doi.org/10.3389/ fnmol.2019.00314.

60. Martínez-García M.Á., Ojeda-Ojeda M., RodríguezMartín E., Insenser M., Moncayo S., Álvarez-Blasco F., LuqueRamírez M., Escobar-Morreale H.F. TLR2 and TLR4 surface and gene expression in white blood cells after fasting and oral glucose, lipid and protein challenges: influence of obesity and sex hormones. Biomolecules 2020; 10(1): 111, https://doi. org/10.3390/biom10010111.

61. Lee G.L., Chang Y.W., Wu J.Y., Wu M.L., Wu K.K., Yet S.F., Kuo C.C. TLR 2 induces vascular smooth muscle cell migration through CAMP response element-binding proteinmediated interleukin-6 production. Arterioscler Thromb Vasc Biol 2012; 32(11): 2751-2760, https://doi.org/10.1161/ atvbaha.112.300302.

62. Luo L., Lucas R.M., Liu L., Stow J.L. Signalling, sorting and scaffolding adaptors for toll-like receptors. J Cell Sci 2019; 133(5): jcs239194, https://doi.org/10.1242/jcs.239194.

63. Schoneveld A.H., Oude Nijhuis M.M., van Middelaar B., Laman J.D., de Kleijn D.P., Pasterkamp G. Toll-like receptor 2 stimulation induces intimal hyperplasia and atherosclerotic lesion development. Cardiovasc Res 2005; 66(1): 162-169, https://doi.org/10.1016/j.cardiores.2004.12.016.

64. Kobayashi N., Suzuki J., Ogawa M., Aoyama N., Komuro I., Izumi Y., Isobe M. Porphyromonasgingivalis promotes neointimal formation after arterial injury through tolllike receptor 2 signaling. Heart Vessels 2014; 29(4): 542-549, https://doi.org/10.1007/s00380-013-0405-3.

65. Zhang Y., Xia G., Zhang Y., Liu J., Liu X., Li W., Lv Y., Wei S., Liu J., Quan J. Palmitate induces VSMC apoptosis via toll like receptor (TLR)4/ROS/p53 pathway. Atherosclerosis 2017; 263: 74-81, https://doi.org/10.1007/s00380-013-0405-3.

66. Kiechl S., Lorenz E., Reindl M., Wiedermann C.J., Oberhollenzer F., Bonora E., Willeit J., Schwartz D.A. Toll-like receptor 4 polymorphisms and atherogenesis. N Engl $\mathrm{J}$ Med 2002; 347(3): 185-192, https://doi.org/10.1056/nejmoa012673.

67. Kale J., Osterlund E.J., Andrews D.W. BCL-2 family proteins: changing partners in the dance towards death. Cell Death Differ 2018; 25(1): 65-80, https://doi.org/10.1038/ cdd.2017.186.

68. Birkinshaw R.W., Czabotar P.E. The BCL-2 family of proteins and mitochondrial outer membrane permeabilisation. Semin Cell Dev Biol 2017; 72: 152-162, https://doi. org/10.1016/j.semcdb.2017.04.001.

69. Hockings C., Alsop A.E., Fennell S.C., Lee E.F., Fairlie W.D., Dewson G., Kluck R.M. Mcl-1 and Bcl-x sequestration of Bak confers differential resistance to $\mathrm{BH}$-only proteins. Cell Death Differ 2018; 25(4): 721-734, https://doi. org/10.1038/s41418-017-0010-6.

70. Edlich F. BCL-2 proteins and apoptosis: recent insights and unknowns. Biochem Biophys Res Commun 2018; 500(1): 26-34, https://doi.org/10.1016/j.bbrc.2017.06.190. 
71. Walensky L.D. Targeting BAX to drug death directly. Nat Chem Biol 2019; 15(7): 657-665, https://doi.org/10.1038/ s41589-019-0306-6.

72. Opferman J.T., Kothari A. Anti-apoptotic BCL-2 family members in development. Cell Death Differ 2018; 25(1): 3745, https://doi.org/10.1038/cdd.2017.170.

73. Peña-Blanco A., García-Sáez A.J. Bax, Bak and beyond - mitochondrial performance in apoptosis. FEBS $J$ 2018; 285(3): 416-431, https://doi.org/10.1111/febs.14186.

74. Pollman M.J., Hall J.L., Mann M.J., Zhang L., Gibbons G.H. Inhibition of neointimal cell bcl-x expression induces apoptosis and regression of vascular disease. Nat Med 1998; 4(2): 222-227, https://doi.org/10.1038/nm0298-222.

75. Zhang J., Huang K., O'Neill K.L., Pang X., Luo X. Bax/Bak activation in the absence of Bid, Bim, Puma, and p53. Cell Death Dis 2016; 7: e2266, https://doi.org/10.1038/ cddis.2016.167.

76. Bogner C., Kale J., Pogmore J., Chi X., Shamas-Din A., Fradin C., Leber B., Andrews D.W. Allosteric regulation of $\mathrm{BH} 3$ proteins in $\mathrm{Bcl}-\mathrm{x}_{\mathrm{L}}$ complexes enables switch-like activation of Bax. Mol Cell 2020; 7(4): 901-912.e9, https://doi.org/10.1016/j. molcel.2019.12.025.

77. Borrás C., Mas-Bargues C., Román-Domínguez A., Sanz-Ros J., Gimeno-Mallench L., Inglés M., Gambini J., Viña J. Bcl-xL, a mitochondrial protein involved in successful aging: from $\mathrm{C}$. elegans to human centenarians. Int J Mol Sci 2020; 21(2): 418, https://doi.org/10.3390/ijms21020418.

78. Chung S., Roy A.K., Webster T.J. Selenium nanoparticle protection of fibroblast stress: activation of ATF4 and Bcl-xL expression. Int J Nanomedicine 2019; 14: 9995-10007, https:// doi.org/10.2147/ijn.s172236.

79. Gupta A., Shah K., Oza M.J., Behl T. Reactivation of p53 gene by MDM2 inhibitors: a novel therapy for cancer treatment. Biomed Pharmacother 2019; 109: 484-492, https:// doi.org/10.1016/j.biopha.2018.10.155.

80. Zhang L., Gao W., Keohavong P. Analysis of mutations in K-ras and p53 genes in sputum and plasma samples. Methods Mol Biol 2020; 2102: 373-394, https://doi.org/10. 1007/978-1-0716-0223-2 22.

81. Tzovaras A.A., Gentimi F., Nikolaou M. Tumor protein p53 gene and cardiovascular disease. Angiology 2018; 69(8): 736-737, https://doi.org/10.1177/0003319718772412.

82. Miyashita T., Reed J.C. Tumor suppressor p53 is a direct transcriptional activator of the human bax gene. Cell 1995; 80(2): 293-299, https://doi.org/10.1016/00928674(95) $90412-3$.

83. Wu D., Prives C. Relevance of the p53-MDM2 axis to aging. Cell Death Differ 2018; 25(1): 169-179, https://doi. org/10.1038/cdd.2017.187.

84. Wurz R.P., Cee V.J.Targeted degradation of $\mathrm{mdm} 2$ as a new approach to improve the efficacy of mdm2-p53 inhibitors. Med Chem 2019; 62(2): 445-447, https://doi.org/10.1021/acs. jmedchem. 8 b0 1945.

85. Tanaka K. Zou J.P. Takeda K., Ferrans V.J., Sandford G.R., Johnson T.M., Finkel T., Epstein S.E. Effects of human cytomegalovirus immediate-early proteins on p53-mediated apoptosis in coronary artery smooth muscle cells. Circulation 1999; 99(13): 1656-1659, https://doi. org/10.1161/01.cir.99.13.1656.

86. Guevara N.V., Kim H.S., Antonova E.I., Chan L. The absence of p53 accelerates atherosclerosis by increasing cell proliferation in vivo. Nat Med 1999; 5(3): 335-339, https://doi. org/10.1038/6585.
87. Jacob T., Hingorani A., Ascher E. p53 gene therapy modulates signal transduction in the apoptotic and cell cycle pathways downregulating neointimal hyperplasia. Vasc Endovascular Surg 2012; 46(1): 45-53, https://doi. org/10.1177/1538574411422277.

88. Gerber H.P., Dixit V., Ferrara N. Vascular endothelial growth factor induces expression of the antiapoptotic proteins $\mathrm{Bcl}-2$ and $\mathrm{A} 1$ in vascular endothelial cells. $J$ Biol Chem 1998; 273(21): 13313-13316, https://doi.org/10.1074/ jbc.273.21.13313.

89. Svetozarskiy N.L., Artifeksova A.A., Svetozarskiy S.N. Growth promoting factor of endothelium of vessels: biological properties and practical value (literature review). Meditsina $i$ obrazovanie v Sibiri 2015; 5: 24-32.

90. Duran X., Vilahur G., Badimon L. Exogenous in vivo NO-donor treatment preserves p53 levels and protects vascular cells from apoptosis. Atherosclerosis 2009; 205(1): 101-106, https://doi.org/10.1016/j.atherosclerosis.2008.11.016.

91. Spiguel L.R., Chandiwal A., Vosicky J.E., Weichselbaum R.R., Skelly C.L. Concomitant proliferation and caspase-3 mediated apoptosis in response to low shear stress and balloon injury. J Surg Res 2010; 161(1): 146-155, https://doi. org/10.1016/j.jss.2008.11.001.

92. Lee M., Rey K., Besler K., Wang C., Choy J. Immunobiology of nitric oxide and regulation of inducible nitric oxide synthase. Results Probl Cell Differ 2017; 62: 181-207, https://doi.org/10.1007/978-3-319-54090-0_8.

93. Boyd C.S., Cadenas E. Nitric oxide and cell signaling pathways in mitochondrial-dependent apoptosis. Biol Chem 2002; 383(3-4): 411-423, https://doi.org/10.1515/ bc. 2002.045 .

94. Takahashi A., Masuda A., Sun M., Centonze V.E. Oxidative stress-induced apoptosis is associated with alterations in mitochondrial caspase activity and $\mathrm{Bcl}-2$ dependent alterations in mitochondrial $\mathrm{pH}\left(\mathrm{pH}_{\mathrm{m}}\right)$. Brain Res Bull 2004; 62(6): 497-504, https://doi.org/10.1016/j. brainresbull.2003.07.009.

95. Chae I.H., Park K.W., Kim H.S., Oh B.H. Nitric oxideinduced apoptosis is mediated by $\mathrm{Bax} / \mathrm{Bcl}-2$ gene expression, transition of cytochrome $\mathrm{C}$, and activation of caspase-3 in rat vascular smooth muscle cells. Clin Chim Acta 2004; 341(1-2): 83-91, https://doi.org/10.1016/j.cccn.2003.11.009.

96. Choi B.M., Pae H.O., Jang S.I., Kim Y.M., Chung H.T. Nitric oxide as a pro-apoptotic as well as anti-apoptotic modulator. J Biochem Mol Biol 2002; 35(1): 116-126, https:// doi.org/10.5483/bmbrep.2002.35.1.116.

97. Chung H.T., Pae H.O., Choi B.M., Billiar T.R., Kim Y.M. Nitric oxide as a bioregulator of apoptosis. Biochem Biophys Res Commun 2001; 282(5): 1075-1079, https://doi. org/10.1006/bbrc.2001.4670.

98. Dubey M., Nagarkoti S., Awasthi D., Singh A.K., Chandra T., Kumaravelu J., Barthwal M.K., Dikshit M. Nitric oxide-mediated apoptosis of neutrophils through caspase-8 and caspase-3-dependent mechanism. Cell Death Dis 2016; 7(9): e2348, https://doi.org/10.1038/cddis.2016.248.

99. Li X., Shang B., Li Y.N., Shi Y., Shao C. IFN $\gamma$ and TNFa synergistically induce apoptosis of mesenchymal stem/stromal cells via the induction of nitric oxide. Stem Cell Res Ther 2019; 10(1): 18-24, https://doi.org/10.1186/s13287-018-1102-z.

100. Zhang N., Diao Y., Hua R., Wang J., Han S., Li J., Yin $Y$. Nitric oxide-mediated pathways and its role in the degenerative diseases. Front Biosci (Landmark Ed) 2017; 22: 824-834, https://doi.org/10.2741/4519. 